\title{
The Effects of Security and Privacy Information on Trust \& Trustworthiness and Loyalty in Online Marketing in Malaysia
}

\author{
Hamed Armesh \\ Multimedia Univesity, Malaysia \\ E-mail: hamed_dba@yahoo.com \\ Habibollah Salarzehi \\ University of Sistan and Baluchestan, Iran \\ Noor Mohammad Yaghoobi \\ University of Sistan and Baluchestan, Iran \\ Alireza heydari \\ Multimedia Univesity, Malaysia \\ E-mail: alireza_dba2009@yahoo.com
}

Davoud Nikbin

School of Management, Universiti Sains Malaysia, Malaysia

\begin{abstract}
The internet is a medium that is soaring in polarity in almost every facet of the world and is used for a myriad of reasons by individuals, governments, universities and businesses. As far as businesses are concerned, the internet has been subject to a variety of experimentations that seek to determine the viability of using the internet to improve business practices in various industries especially in computer industry in Malaysia. One particular aspect of business is that the internet marketing has a great impact on computer industry in Malaysia. The purpose of this research is to investigate the effects of security and privacy information on trust \& trustworthiness and loyalty in online marketing. Data were gathered from 104 respondents who are the literate Malaysian and the foreigners in Malaysia that are able to read and write and hence capable of using internet and its facilities. The results showed that there is a significant correlation between trust $\&$ trustworthiness and security and privacy information. The results also revealed that there is a significant correlation between loyalty in online marketing and trust \& trustworthiness.
\end{abstract}

Keywords: Loyalty, Customer satisfaction, Customer trust, Customer behavior, Computer Industry/Computer Related Product

\section{INTRODUCTION}

The growth of the internet has led to a serious mass of consumers and firms participating in a global online market or e-commerce. Internet has been used as a commercial medium for transaction across the borderless world in computer-mediated environment. The rapid growth of internet usage has transformed its function beyond as a medium of communication to a brand new market arena (Ricciuti, 1995). The dramatic increase in internet and the detonation of its usage have facilitated the development of electronic commerce, which is described as the movement of buying and selling, or the trading of products, service and information between and among the organizations and individuals all the way through computer networks including the internet (Laudon \& Traver, 2001). When investing in online/internet marketing, strategic thinking will bring to the best rewards (Scanlon, 2009).

The major revolution is the internet, which is really used for marketing products and services. According to a statement from e-Gain Communication an approximated 6.6 billion USD worth of merchandises are currently being existing on the Internet/online marketing for more than 200 million users. 35 million of them are assumed to 
be involved actively in the online marketing world. This represents a vast would-be the online ventures by business organizations and the participation of net users exponentially.

Despite this though, online sales or online marketing continue to develop as internet-based businesses become more complicated; indeed many users stay involved in online shopping. Understanding possible markets is thus important for businesses investing in electronic commerce. Amichai-Hamburger (2002) indicated that the behavior of internet users plays a significant role in their online behavior. Moreover, Hills and Argyle (2003) reached similar viewpoints. They found that individual internet use correlates with individual personality differences. Kotler (2003) asserted that personal factors are the main persuade on buyer behavior. Thus, understanding the personality differences between these two groups (internet shoppers or online purchasers and non-internet shoppers or non-online purchasers) is really important to businesses. Understanding the personality of potential online customers can help businesses accurately target prospective markets.

Business organizations in the computer industry these days are facing increasingly competing difficulties domestically and internationally. What these business organizations (computer industry) need here is a new and innovative way of marketing their services to the world and the specific country like Malaysia. Computer industries need a new method for marketing that is radically different from traditional marketing methodologies that have been used in the past, as traditional marketing methods are now starting to become obsolete. These companies (computer industries) are facing difficulties in using traditional marketing tools and are in need of something more effective and far reaching. This research aims to provide answers to these problems by examining the positive and negative impact of internet on marketing in Malaysia and also the consumer shopping behaviors online then determining the viability of business organizations in the computer industry in utilizing the internet as their marketing tool of choice.

\section{LITERATURE REVIEW}

\section{Security}

Kalakota and Whinston (1996) define a security threat as a circumstance, condition, or event with the potential to cause economic hardship to data or network resources in the form of destruction, disclosure, modification of data, denial of service, and fraud, waste, and abuse. Despite the fact that security positively influences intention to purchase online (Ranganathan \& Ganapathy 2002; Salisbury et al., 1998), it remains one of the major concerns (Kiely 1997; Mardesich 1999; Mayer et al., 1995). Many consumers are still reluctant to release payment card information to online merchants, fearing a loss of control over their accounts. Merchants and financial institutions, in turn, are concerned about the costs associated with online charge backs and fraud. To alleviate customers' fears, many B2C Websites offer alternate forms of payment (e.g. telephone ordering) and/or accounts with ID's and passwords (Ranganathan \& Ganapathy 2002). Bélanger et al., (2002) found that the presence of security features on an e-commerce site was important to consumers, and discuss how consumers' security concerns may be addressed by similar technology protections as those of the business, such as encryption and authentication. In this study, the features evaluated within the attribute of security include: (1) whether the site provides encryption, (2) whether the site requires the user to set up an account with an ID and password, and (3) whether a confirmation screen is displayed after the completion of the purchase to ensure accuracy.

\section{Privacy}

Privacy in e-commerce is defined as the willingness to share information over the Internet that allows for the conclusion of purchases (Belanger et al. 2002). B2C Web sites gather information about visitors via explicit modes (e.g. surveys) and implicit means (e.g. cookies) (Patterson et al. 1997), providing the necessary data for decision making on marketing, advertising, and products. However, many users have concerns over potential misuse of personal information (Brown \& Muchira, 2004; Hair et al., 1995; Ranganathan \& Ganapathy, 2002; Torkzadeh \& Dhillon, 2002). For example, a Business Week/Harris poll of 999 consumers in 1998 revealed that privacy was the biggest obstacle preventing them from using Websites, above the issue of cost, ease of use, and unsolicited marketing (Green et al. 1998). An IBM Multi-National Consumer Privacy survey in 1999 showed that $80 \%$ of the U.S. respondents felt that they had lost all control over how personal information is collected and used by companies. Seventy-eight percent had refused to give information because they thought it was inappropriate in the circumstance, and $54 \%$ had decided not to purchase because of concerns over the use of their information collected during the transaction (Belanger et al., 2002). A study by Forrester Research supports these findings, showing that two-thirds of consumers are worried about protecting personal information online (Branscum, 2000). To address issues of privacy, many Websites display privacy policies (McGinity, 2000). Also, independent companies (e.g. TRUSTe) can verify, audit, and certify privacy policies (Ranganathan \& Ganapathy, 2002). In this study, the features evaluated within the attribute of privacy are: (1) the use of a privacy statement, 
(2) the merchant's policy on selling customer information to third parties, and (3) the use of cookies to collect personal information.

\section{Trust \& Trustworthiness}

Trust is the willingness to rely on an exchange partner in whom one has confidence (Prasarnphanich, 2007). Trust consists of two distinct dimensions: credibility and benevolence (Prasarnphanich, 2007). Credibility refers to the extent to which the buyer or supplier believes that the other party has the required expertise to perform the job effectively and reliably (i.e., an ability of the partner to deliver as promised). Benevolence refers to the extent to which the buyer is genuinely interested in the other partner's welfare and motives to seek joint gain (Prasarnphanich, 2007). This benevolence dimension is consistent with the issue of privacy and security concerns that vendors do their best efforts to protect customers' personal information and prevent any personal losses due to their interaction with the vendors (Prasarnphanich, 2007). The benevolence dimension of trust can exist even when the objective credibility of vendors is less than perfect. For example, customers might feel that the vendor is still concerned with their personal welfare, even though the vendor's services are somewhat unreliable (Prasarnphanich, 2007). Shopping factors focus on customers' feelings and perceptions during and after the shopping experience. Factors determining this include convenience, trust and trustworthiness of Web merchants, and delivery time (Bélanger et al., 2002; Keeney, 1999; Nielsen, 2000 Patterson et al., 1997; Torkzadeh \& Dhillon 2002). The prototypical online consumer leads a wired lifestyle and is time starved, suggesting that online shoppers may do so to save time (Bellman et al., 1999). This indicates that the overall convenience of the shopping experience is very important as well as the amount of time it takes for the product to be received. Trust is of importance during the actual shopping experience because if the consumer does not trust the merchant to make good on their purchase a transaction will not take place. Three features of each attribute (convenience, trust, and delivery) will be evaluated using a conjoint analysis to get a preferred feature within each attribute as well as determining an overall ranking of each attribute, including an overall importance score of each attributes.

\section{Customer Loyalty}

Zeithaml (2000) states that previous studies viewed customer loyalty as being either behavioral or attitudinal. The behavioral approach is that customers are loyal as long as they continue to buy and use a good or service (Woodside et al., 1989; Parasuraman et al., 1988; Zeithaml et al., 1996). The behavior approach includes criteria such as repeat purchase, share-of-wallet, and word of mouth referrals, whereas the attitudinal approach consists of criteria like commitment, trust or emotional attachment. The attitudinal approach is that customers feel a sense of belonging or commitment to the good or service. Baumann et al., (2005) noted that Day (1969) four decades ago introduced the concept that loyalty has both behavioral and attitudinal dimensions.

Customer loyalty has been recognized by a large number of authors as one of the key topics in Internet that deserves a great deal of attention. According to Griffin (1996), one of the most exciting and successful uses of this revolutionary technology may be the Internet's role in building customer loyalty and maximizing sales to your existing customers. One of the reasons for the importance of loyalty in the online context according to Rayport and Sviokla (1994) is the changing role of the content, the context, and the infrastructure in the marketplace.

Loyal customers are undoubtedly important because they contribute to the profitability of the service providers (Anderson \& Mittal, 2000; Anderson \& Sullivan, 1993). They visit a website more frequently than a newly acquired customer and can be served at a reduced operating cost. They provide free word-of-mouth advertising and are likely to pay regular prices. In a recent update on e-loyalty, Reichheld and Schefter (2000, p.107) observed that contrary to current beliefs 'price does not rule the Web; trust does. According to the authors, referrals are extremely important in e-services and may count for half of the acquired customers for some services. Furthermore, referred customers were found to ask for advice and guidance from the loyal customers who recommended the service to them, thus reducing the company's costs for providing help.

\section{Conceptual framework of the study}

In line with literature review and the purpose of study described in the beginning of the paper, the conceptual framework of this study was configured as illustrated in figure 1 (See Appendix). In this framework security and privacy information as the antecedents will affect trust and trustworthiness, (H1, H2). Besides, trust and trustworthiness has a relationship with loyalty in online marketing as the consequence (H3).

$\mathbf{H 1}_{0}$ : There is no significant correlation between trust \& trustworthiness and security.

$\mathbf{H 1}_{1}$ : There is significant correlation between trust \& trustworthiness and security.

$\mathbf{H 2}_{\mathbf{0}}$ : There is no significant correlation between trust \& trustworthiness and privacy information. 
$\mathbf{H 2}_{1}$ : There is significant correlation between trust \& trustworthiness and privacy information.

$\mathbf{H 3}_{0}$ : There is no significant correlation between loyalty in online marketing and trust \& trustworthiness.

$\mathbf{H 3}_{1}$ : There is a significant correlation between loyalty in online marketing and trust \& trustworthiness.

\section{METHOD}

\section{Procedure}

Data was gathered through a well designed structured questionnaire. The survey was personally administered by the researcher so as to have better communication with the respondents. This reduces incorrect answers which might lead to wrong findings and analysis. The total population for this particular study is all the literate Malaysian and the foreigners in Malaysia; these are those who can read and write and hence they are capable of using internet and its facilities. These are the individuals who can get access to internet and make a proper use of the service. A convenience sampling (non-probability sampling) was used for this study. This type of sampling method was used because it gathers information from members of the population who are conveniently available to provide it. 300 questionnaires were distributed among the respondents of this study and due to difficulties of different cast and nationality the researcher could successfully collect 105 questionnaires back and hence the sample size used for data analysis and findings was 104 respondents, and the area where the research has been done (Selangor, Kuala Lumpur, and Penang), mostly at the universities and public places likes coffee shops, and... in Malaysia.

\section{Questionnaire design}

The instrument used for data collection for this study is a self-administered questionnaire. This questionnaire was comprised of 38 questions related to internet marketing and consumer experience in computer product.

The questionnaire was divided into five parts which are loyalty in online marketing, security, privacy information, trust \& trustworthiness, and demographic respectively.

The respondents were given options to choose in answering the questions. The options were as follows; Option 1; choose from the given items and Option 2; choose between 1 to 5 where, 1 stands for strongly disagree, 2 for disagree, 3 for neutral, 4 for agree, and 5 for strongly agree.

\section{RESULTS}

\section{Respondents Demographic Profile}

About 150 questionnaires were distributed to different respondents for data collection and from those 150 questionnaires 100 have done by interviews and 50 by e-mail. Out of those 300,104 questionnaires were returned to the researcher. This marks a $69.33 \%$ response rate. Among the returned questionnaires, 59 have purchased the computer related products online at least once and 45 had never done online purchase before due to a number of reasons. This means $56.73 \%$ of all the respondents have engaged themselves with internet/cyber space to purchase the computer related products online at least once.

The demographic profile of respondents showed that, the sample consisted of Male respondents (online purchased of computer related products) were 40 male which are $67.8 \%$ of all the respondents and 19 female which are $32.2 \%$ of the respondents. $66.1 \%$ of the respondents are singles, $27.1 \%$ of the respondents are married, and $6.8 \%$ of the respondents are divorced. $11.9 \%$ of the online computer related product purchasers have high school and below qualification, $13.6 \%$ of the online computer related product purchasers have diploma qualification, $28.8 \%$ of the online computer related product purchasers have bachelor degree, $35.6 \%$ of the online computer related product purchasers have master degree, $6.8 \%$ of the online computer related product purchasers have $\mathrm{PhD}$ and $3.4 \%$ are professional certificate holders. $20.3 \%$ of the online computer related product purchasers are Malay, $16.9 \%$ of the online computer related product purchasers are Indian, $18.6 \%$ of the online computer related product purchasers are Chinese and $44.1 \%$ of the online computer related product purchasers are others (foreigners).

\section{Hypotheses Testing}

$\mathrm{H1}_{0}$ : There is no significant correlation between trust \& trustworthiness and security.

$\mathrm{H1}_{1}$ : There is significant correlation between trust \& trustworthiness and security.

$\mathrm{H2}_{\mathbf{0}}$ : There is no significant correlation between trust \& trustworthiness and privacy information.

\section{$\mathbf{H} 2_{1}$ : There is significant correlation between trust \& trustworthiness and privacy information.}

Probability from the regression analysis table results also justifies the relationship between trust $\&$ trustworthiness and security in Malaysia. The test gives the p-value of 0.7686 . Since p-value is almost 76.8 percent which is 
higher than 5 percent, we cannot reject null, meaning that security variable cannot influence trust \& trustworthiness individually in the online marketing in Malaysia, because the p-value is more than 0.05 ; and in this test individually we accept null hypothesis and reject alternative hypothesis.

The R-Square value is of 0.974120 and the r-squared should be more than 60 percent and here the R-squared more than 0.60 . That is value of R-squared should be reasonable high, more than 60 percent, the higher the R-squared the fitted data. It means that 97.4 percent variation in trust \& trustworthiness can be explained by two independent variables such as privacy information and security. The rest 2.6 percent variation in trust $\&$ trustworthiness can be explained by residuals or can say other variables other than privacy information and security.

From the regression output table the analysis F-test results also justifies the relationship between trust \& trustworthiness and other independent variables in Malaysia. Independent variables should be jointly significant. This can be checked using F-test. If the p-value of F-statistic is less than 5 percent $(0.05)$ we can reject the null and accept alternative hypothesis. If we can reject null hypothesis, it means that all the independent variables (privacy information and security) jointly can influence dependent variable, which is trust \& trustworthiness here. Since the p-value is less than 5 percent (here 0.00 percent), we can reject the null and accept alternative hypothesis. In other words, it means that all the independent variables (privacy information and security) can jointly explain or influence trust \& trustworthiness.

Therefore, the computer industries should increase their site security and also security of whatever a online computer related products purchaser want to do on their site to buy their product and everything that effect the product and customer should be secure to get the trust and trustworthiness of the online computer industry customers in Malaysia and must combine resources and increase the infrastructure level in the country since this has a direct impact on the online marketing to increase the customer satisfaction and also change the customer behaviour in computer industry in Malaysia. Malaysia needs e-commerce application as other countries do because this will boost it economy and living standard of her citizens and also needs high e-commerce security.

From the above analysis, we are accepting the null hypothesis and rejecting the alternative hypothesis, "There is significant correlation between Trust \& trustworthiness and Security". And also, "There is significant correlation between Trust \& trustworthiness and Privacy information".

\section{$\mathrm{H3}_{0}$ : There is no significant correlation between loyalty in online marketing and Trust \& trustworthiness.}

\section{$\mathrm{H}_{3}$ : There is a significant correlation between loyalty in online marketing and Trust $\&$ trustworthiness.}

Probability from the regression analysis table results also justifies the relationship between loyalty in online marketing and trust and trustworthiness in Malaysia. The test gives the p-value of 0.0021 . Since p-value is almost 0.21 percent which is less than 5 percent, we can reject null, meaning that trust and trustworthiness variable can influence loyalty in online marketing individually in the online marketing in Malaysia, because the p-value is less than 0.05 , and in this test individually we reject null hypothesis and accept alternative hypothesis. Consider table 4.8 below;

The R-Square value is of 0.964395 and the r-squared should be more than 60 percent and here the R-squared more than 0.60 . That is value of R-squared should be reasonable high, more than 60 percent, higher the R-squared better the fitted data. It means that 96.4 percent variation in customer satisfaction can be explained by two independent variables such as customer satisfaction and trust $\&$ trustworthiness. The rest 3.6 percent variation in loyalty in online marketing can be explained by residuals or can say other variables other than customer satisfaction and trust \& trustworthiness. Consider table 4.8 below;

From the regression output table the analysis F-test results also justifies the relationship between loyalty in online marketing and other independent variables in Malaysia. Independent variables should be jointly significant. This can be checked using F-test. If the p-value of F-statistic is less than 5 percent $(0.05)$ we can reject the null and accept alternative hypothesis. If we can reject null hypothesis, it means that all the independent variables (customer satisfaction and trust \& trustworthiness) jointly can influence dependent variable, which is loyalty in online marketing here. Since the p-value is less than 5 percent (here 0.00 percent), we can reject the null and accept alternative hypothesis. In other words, it means that all the independent variables (here customer satisfaction and trust $\&$ trustworthiness) can jointly explain or influence loyalty in online marketing. Consider table 4.8 below;

Therefore, the computer industries should improve their all things or variables that effect or influence the trust \& trustworthiness to increase trust of online purchasers in online marketing and to make the customer loyal in online marketing and also make the computer online customer more satisfied in Malaysia and must combine resources and increase the infrastructure level in the country since this has a direct impact on the online marketing to increase the customer behaviour positively. Malaysia needs e-commerce application as other countries do because this will 
boost it economy and living standard of her citizens and also needs more security services in online business in computer industry.

From the above analysis, we are rejecting the null hypothesis and accept the alternative hypothesis, "There is a significant correlation between loyalty in online marketing and Trust \& trustworthiness".

\section{DISCUSSION}

From the analysis result done at the earlier part of this chapter, demographic factors were examined and their effects on e-commerce or online marketing in computer industry in Malaysia were analyzed critically. Gender and marital status were not included into this demographic factors analysis because there is no much significant difference between gender and marital status in online marketing in computer related products purchaser. Age, education, and ethnicity showed the difference and effect on online marketing in computer related products purchaser in computer industry in Malaysia and showed that they are more satisfied and find the online business with good security and good IT services with computer industry and their behaviour is good and will increase in future by adding some good effective resources in online business in computer industry. Young people have seen to be major users of internet and e-commerce services and online computer related products purchasers, individual aged 30 years and bellows accounts for $76.3 \%$ of all online computer related products purchaser and older individuals' accounts for $23.7 \%$ only. Education as well makes a distinct difference on online marketing level in computer industry, diploma, bachelor degree and masters degree holders' accounts for $78 \%$ of the online computer related products purchaser in Malaysia, and only $22 \%$ is accounted by other education level groups. Ethnicity also makes a distinct difference on online marketing level in computer industry in Malaysia, Malay and others (foreigners) have seen to be major user and online computer related products purchaser and they accounts for $64.4 \%$ of the online purchasers of computer related product in Malaysia, and Indian and Chinese only $35.6 \%$ is accounted so I understood that these groups are more comfortable, more satisfy and more save on online purchasing in computer industry in Malaysia and they also find some positive effect in online business in computer industry in Malaysia.

The analysis of these hypothesis shows that, loyalty of customer in online marketing in computer industry in Malaysia is influenced by trust and trustworthiness; and Trust \& Trustworthiness influenced by privacy information and security has seen to have no significant effect/influence on trust \& trustworthiness in computer industry in Malaysia, but jointly both (privacy information and security) effect/influence on trust \& trustworthiness; So jointly all the variables have a significant effect/influence in loyalty in online marketing in Malaysia.

Furthermore, in this study the main is that the all independent variables jointly have seen to have a significant correlation with loyalty in online marketing or have a significant effect/influence on loyalty and this analyzes showed that the online computer customers trust and they have good behaviour to computer industry in Malaysia. So totally this study found out the online marketing in computer industry in Malaysia very effective and positive to the online computer products customers.

\section{IMPLICATIONS}

The practical implication and contribution of this study to the body of knowledge comes from the survey and findings of the study. Online marketing players (computer industry) in Malaysia have started to take initiatives to understand their online clients and/or customers (online purchasers) as far as their perceptions, attitudes and habits are concerned. According to the demographic analysis of the findings, the sector should re-look their strategies so as to incorporate all users of internet and ICT services regardless of their education or age and ethnicity. They should use different strategies and tactics to tackle different groups of customers and hence online marketing and e-commerce adoption in computer industry in Malaysia will be a success story.

Its undeniable fact the internet technology and e-commerce requires huge investment in terms of monetary capital and knowledge/human capital. Therefore, online marketing players in computer industry in Malaysia must really look into prospective adopters and take respective measures to make sure that they adopt and make use of internet and e-commerce services in the country.

From the conducted survey we have seen some important factors which impact of online marketing or influence of online marketing in computer industry in Malaysia. Therefore the sector must survey each of the factors in details and see how they can take advantage of each factor in increasing online purchasers and e-commerce usage in computer industry in Malaysia. This can only be achieved with more research on each factor and put the findings of the researches into practical use and hence accelerate the rate of online purchasers in computer industry in Malaysia. 
Online marketing and e-commerce awareness is still not reached to develop countries among Malaysians. No one will adopt or use e-commerce/online marketing in computer industry if he/she doesn't know about it. Therefore, the sector and government must take strong measures to increase awareness among the internet users and online purchasers and later on to non-users of internet. These measures will increase internet users and hence the same will apply to online purchasers or e-commerce users.

ICT and internet/online security was ranked as the highest hindrance towards online marketing in computer industry in Malaysia. Every internet user and online purchaser needs to feel secured when using the service or otherwise they will not use the service. Online purchasing and e-commerce need personal information and banking information of an individual, this makes it so important for internet and e-commerce service providers to assure security to their clients and customers while and after using their services. By dealing with this security threat, confidence on internet and e-commerce services will grow among internet users and online purchasers in computer industry and hence it won't be a threat to those who are using internet and e-commerce services and even to those who are adopting online marketing and e-commerce. Survey showed that, those who have adopted online marketing and e-commerce they don't feel very secured when doing online purchase and e-commerce (online transactions) and those who are not using e-commerce and internet services are failing to adopt because of the security reasons.

\section{LIMITATION OF THE STUDY}

The online marketing sector is small not that big in Malaysia and it is on a growing stage. This stage of Malaysia's online marketing sector in computer industry in enhancing customer experience makes it difficult to find sufficient and relevant literature about the online marketing in computer industry in Malaysia. Most of the information collected for the literature review are from other countries and explain online marketing and some how e-commerce situation in other countries such as US, Australia, UK, etc, and some from Malaysia. The other countries online marketing literature might not be very accurate and suitable to explain online marketing in computer industry condition in Malaysia due to differences in culture and economic strength.

Questionnaire was used as a tool for primary data collection for this study. Even though, the questionnaire questions were set with multiple choices for respondents to choose, but it might lead to wrong choices due to misunderstanding the order of choices or respondents' biases. This makes questionnaire not to be flexible and limits respondents to answer questions based on the choices given by the researcher and not what they think might be the appropriate answer. This might have caused biases in the responses.

The sample population for this study was 104 respondents and among 104 respondents 59 able to purchase the computer related product online. These respondents are from various ethnic, age and education groups. The findings could have been more accurate and more reliable if the sample size was bigger than this. The higher the sample size the higher the significance of the findings. More than 150 questionnaires were sent out but only 59 were replied. Therefore, there is a low response rate for mail and interview questionnaire method of data collection. However, due to time constraints, fund and availability of man power, this sample size had to be used for the study.

\section{DIRECTIONS FOR FURTHER RESEARCH}

Factors found in this study are not the only factors that internet/online marketing influence on computer industry in Malaysia. More attitudinal factors which were not included in this study can be explored to further explain the online marketing in computer industry in Malaysia. Comparison between individual internet users and/or online purchaser and non-users and/or non-online purchaser on the factors influencing or hinders them from adopting online marketing and e-commerce can be done for more accuracy. Larger sample can be used in further studies to improve the accuracy and reliability of the findings.

The future researches on Malaysia's online marketing in computer industry situation must be conducted on a more wide geographical area. This will make the results to be more representative than results from one or few regions only. Similar study has been done in other countries but few studies had been done for the Southeast Asia region, so I here by encourage researchers to do more research on online marketing in computer industry on the Southeast Asia region this will influence the adoption and usage of internet and online marketing in computer industry in the region.

At the last, more research should be done on the online marketing area focusing on computer industry. This will help to know what it takes for the computer industry in Malaysia to adopt online marketing in their business environment; if the computer industry adopts it will be easier to spread adoption to the customers. 


\section{CONCLUSION}

The purpose of this research is to investigate the effects of security and privacy information on trust \& trustworthiness and loyalty in online marketing. Data were gathered from 104 respondents who are the literate Malaysian and the foreigners in Malaysia that are able to read and write and hence capable of using internet and its facilities. The results showed that there is a significant correlation between trust \& trustworthiness and security and privacy information. The results also revealed that there is a significant correlation between loyalty in online marketing and trust \& trustworthiness. The results of this study will be useful to the online marketers in Malaysia in order to enhance the loyalty of their customer and consequently generate more revenue.

\section{References}

Abou Aish ,E.M., Kortam W. A., and Hassan, S. S. (2008). Using agency theory in understanding switching behavior in b2b service industries "I", Working Paper No. 6, January 2008, accessed 1/8/2009, [Online] Available: http://mgt.guc.edu.eg/wpapers/006abouaish_kortam_hassan2008.pdf

Adam, S., R. Mulye, K.R. Deans and D. Palihawadana. (2002). E-marketing in perspective: A three country comparison of business use of the Internet. Marketing intelligence and Planning.

Ahasanul Haque and Ali Khatibi. (2006). Identifying Pontentiality online Sales in Malaysia: A Study on Customer Relationships online Shopping.

Ahasanul Haque and Ali Khatibi. (2006). The study of the behavior of Malaysian consumer towards online shopping.

Ahasanul Haque and Ali Khatibi. (2007). The Impact of internet marketing on customer satisfaction in Malaysia. International Islamic University.

Alba, J., Lynch, J.W.B., Janiszewski, C., Lutz, R., Sawyer, A., and Wood, S. (1997). Interactive home shopping: Consumer, retailer, and manufacturer incentives to participate in electronic marketplace.

Allard C.R Van Riel, Jos Lemmink and Sandra Streukens. (2004). Boost customer loyalty with online support: the case of mobile telecoms providers.

Anderson, E.W., and Mittal. V. (2000). Strengthening the satisfaction-profit chain.

Anderson, E.W., and Sullivan. M.W. (1993). The antecedents and consequences of customer satisfaction for firms.

Apnizan Abdullah, Yusniza Kamarulzaman, \& Abdul Ghani Farida. (2008). Legal Services and Marketing limitation: A Focus on SME in Malaysia.

Baldinger, A.L., and Rubinson,J. (1996). Brand loyalty: the link between attitude and behavior.

Bansal, H. S., Irving, P. G., and Taylor, S. F. (2004). A three-component model of customer commitment to service providers. Journal of the Academy of Marketing Science, 32 (3): 234-50.

Baumann, C., Burton, S., and Elliott, G. (2005). Determinants of customer loyalty and share of wallet in retailing banking.

Blattburg, R.C., and Deighton, J. (1991). Interactive marketing: exploiting the new age of addressability. Sloan Management Review, Fall.

Cecil, J., and Goldstein, M. (1990). Sustaining competitive advantage from IT. McKinsey Quarterly, Vol. 4, pp. 74-89.

Chen, Z., and Dubinsky, A.J. (2003). A conceptual model of perceived customer value in e-Commerce.

Childers, T.L., Carr C.L., Peck J., and Carson S. (2001). Hedonic and utilitarian motivations for online retail shopping behaviour.

Christine Tam Tsui Wa, An integrated online customer loyalty model.

Chung-Hoon Park, \& Young-Gul Kim. (2003). Identifying key factors affecting consumer purchase behavior in an online shopping context. International Journal of Retail \& Distribution Management, 31(1), 16-29. Retrieved August 7, 2009, from ProQuest Central. (Document ID: 284171651).

Cole, R.E. (1985). Target information for competitive performance. Harvard Business Review, May-June, pp. $100-9$

Cox A, Chicksand L, \& Ireland P. (2002). The impact of the Internet on marketing and sales. Journal of Qualitative Market Research: An International Journal. Year 2002, Volume 5, Issue 1 
Davis, F.D., Bagozzi, R.P., and Warshaw, P.R. (1992). Extrinsic and intrinsic motivation to use computers in the workplace.

Day, G.S., and Montgomery, D.B. (1999). Charting new directions for marketing. Journal of Marketing, Vol. 63, pp. 3-13

De Ruyter, K, Wetzels. M, and Bloemer. J. (1998). On the relationship between perceived service quality, service loyalty and switching cost.

De Ruyter, Ko., \& Bloemer, J. (1999). Customer loyalty in extended service settings: The interaction between satisfaction, value attainment and positive mood. International Journal of Service Industry Management, 10(3), 320. Retrieved June 2, 2009, from ProQuest Central.

Devaraj, S., Fan, M., and Kohli, R. (2002). Antecedents of B2C channel satisfaction and preference: Validating e-Commerce metrics.

Earl M.J. (1989). Management Strategies for Information Technology. Prentice-Hall, Hemel Hempstead

Elizabeth M.Lloyd (chief marketing officer). (2007). Marketing to Malaysian Index: Internet Policy in Malaysia.

Ellsworth J.H., and Ellsworth M.V. (1996). Marketing on the Internet - Multimedia Strategies for the WWW, John Wiley, New York, NY, [Online] Available: http://www.oak-ridge.com/orr.html

Fatimah Mohd Arshad, E-Commerce for Agricultural Marketing in Malaysia.

Feeny, D. (1988). Creating and sustaining competitive advantage with IT. in Earl, M.J. (Ed.), Information Management: The Strategic Dimension, Oxford University Press, Oxford

Gefen, D. (2002). Customer loyalty in e-Commerce. Journal of the Association for Information Systems.

Gronhaug, K., and Gilly M. (1991). A transaction cost approach to customer dissatisfaction and complaint actions. Journal of Economic Psychology, (12), pp 165-183

Gronroos, C. (1990). Relationship approach to marketing in service contexts.

Gwo-Guang Lee, \& Hsiu-Fen Lin. (2005). Customer perceptions of e-service quality in online shopping. International Journal of Retail \& Distribution Management, 33(2/3), 161-176. Retrieved September 7 , 2009, from ProQuest Central. (Document ID: 833985871).

Hamill J. (1997). The Internet and international marketing. International Marketing Review, Vol. 14 No. 5, 1997, pp. 300-323 @ MCB University Press, 0265-1335

Hee-Su. K and Yoon, C.H. (2004). Determinants of subscribe churn and customer loyalty in the Korean mobile telephony market.

Hoey C (1998). Maximising the effectiveness of Web-based marketing communications. Marketing Intelligence \& Planning, 16/1 [1998] 31-37

Joseph, W.B., Cook, R.W., and Javalgi, R.G. (2001). Marketing on the Web: how executives feel, what businesses do. Business Horizons, Vol. 44 No. 4, pp. 32-41.

Keaveney, S., and Parthasarathy, M. (2001). Customer switching behavior in online services: an exploratory study of the role of selected attitudinal, behavioral and demographic factors. Journal of the academy of marketing science, (29) (4), pp374-390

Keeney, R.L. (1999). The value of Internet commerce to the customer.

Kiani, G. (1998). Marketing opportunities in the digital world. Internet Research, Vol. 8 No. 2, pp. 185-94

Leong E, Ewing E, \& Pitt L. (2002). Australian marketing managers' perceptions of the Internet: A quasi-longitudinal perspective. European Journal of Marketing, Vol. 37 No. 3/4, 2003, pp. 554-571

Lyons, K. (2001). Why online is the hardest sell, B\&T Weekly, April, [Online] Available: www.bandt.com.au/articles/a3/0c0033a3.aspp

McFarlan, W.E. (1984). Information technology changes the way you compete. Harvard Business Review, May-June

McKinney, V.M., Yoon, K., and Zahedi, F. (2002). The measurement of web-customer satisfaction: An expectation and disconfirmation approach. Information System Research. 
Minjoon Jun, Zhilin Yang, \& DaeSoo Kim. (2004). Customers' perceptions of online retailing service quality and their satisfaction. The International Journal of Quality \& Reliability Management, 21(8), 817-840. Retrieved September 7, 2009, from ProQuest Central. (Document ID: 729592621).

Mohaiminah Hj Khayon and Professor Dr.Rose Alinda Alias. (2006). Exploitation of ICT Strategic Education Marketing in Malaysia Public Institution of Higher Learning. University Teknologi Malaysia.

Mohammad Nazir Ahmad Sharif, Ng Moon Ching, Aryati Bakri, Nor Hidayati Zakaria. (2005). Using a Priori Algorithm for Supporting an E-Commerce System. University Teknologi Malaysia.

Morris, M.H., Marais, P., and Weir, J. (1997). Is the Web world wide? Marketing effects in an emerging market. Journal of Strategic Marketing, Vol. 5 No. 4, pp. 211-31

Nelson Oly Ndubisi, \& Tam Yin Ling. (2006). Complaint behaviour of Malaysian consumers. Management Research News, 29(1/2), 65-76. Retrieved August 7, 2009, from ProQuest Central. (Document ID: 1012272941)

Oliver, Richard L. (1999). Whence customer loyalty.

Parasuraman, A., Zeithaml, V., and Berry, L. (1988). SERVQUAL: A multiple-item scale for measuring consumer perceptions of service quality.

Parasuraman, A., Zeithaml, V., and Berry, L.L. (1991). Refinement and reassessment of the SERVQUAL instrument.

Pattarawan prasarnphanich. (2007). Does trust matter to develop customer loyalty in online business.

Paul P. (1996). Marketing on the Internet. Journal of Consumer Marketing, Vol. 13 No. 41996 pp. 27-39 (C) MCB UNIVERSITY PRESS. 0736-3761

Paul W Ballantine. (2005). Effects of interactivity and product information on consumer satisfaction in an online retail setting. International Journal of Retail \& Distribution Management, 33(6/7), 461-471. Retrieved September 7, 2009, from ProQuest Central. (Document ID: 877315981).

Peppard J. (1993). IT Strategy for Business. Pitman Publishing, London.

Peterson. (1998). A national consumer satisfaction.

Porter, M.E., and Miller, V.E. (1985). How information gives you competitive advantage. Harvard Business Review, July-August

Racherla, P. (2009). Factors influencing consumers' trust perceptions of online product reviews: A study of the tourism and hospitality online product review systems. Ph.D. dissertation, Temple University, United States -Pennsylvania. Retrieved July 22, 2009, from Dissertations \& Theses: Full Text. (Publication No. AAT 3320030).

Richard L Oliver, \& Mikhael Shor. (2003). Digital redemption of coupons: Satisfying and dissatisfying effects of promotion codes. The Journal of Product and Brand Management, 12(2/3), 121. Retrieved August 7, 2009, from ProQuest Central. (Document ID: 358263671).

Sekaran Uma. (2003). Research Methods for Business, $4^{\text {th }}$ edition, John Wiley \& Sons., New York.

Shama, A. (2001). E-coms and their marketing strategies. Business Horizons, Vol. 44 No. 5, pp. 14-20

Shim, J.P., Shin, Y.B., and Nottinghan, L. (2002). Retailer web site influence on customer shopping: An exploratory study on key factors of customer satisfaction. Journal of the Association for Information Systems.

Smith, R. E., and Wright, W.F. (2004). Determinants of customer loyalty and financial performance.

Srinivasan, S.S., Anderson, R., and Ponnavolu, K. (2002). Customer loyalty in e-commerce: An exploration of its antecedents and consequences.

Teo, H.H., Oh, L.B., Liu, C., \& Wei, K.K. (2003). An empirical study of the effect of interactivity on web user attitude. International Journal of Human-Computer Studies.

Torkzadh, G., and Dhillon, G. (2002). Measuring factors that influence the success of Internet commerce.

Toyin A.Clotty, David A. Collier, \& Michael Stodnick. (2008). Drivers of customer loyalty in a retaile store environment.

Turbin, E., McLean, E., and Wetherbe, J. (1996). Information Technology for Management: Improving Quality and Productivity. John Wiley, New York, NY

Ward, J., Griffiths, P., and Whitmore, P. (1996). Strategic Planning for Information Systems. Prentice-Hall, Englewood Cliffs, NJ 
Warrington, Patricia Taylor. (2002). Customer evaluations of e-shopping: The effects of quality-value perceptions and e-shopping satisfaction on e-shopping loyalty. Ph.D. dissertation, The University of Arizona, United States -Arizona. Retrieved September 7, 2009, from Dissertations \& Theses: Full Text.(Publication No. AAT 3060949).

Wolfinbarger, Mary F., and Mary C. Gilly. (2001). Shopping online for freedom, control and fun.

Woodside, A, G., Frey, L.L, \& Daly,R.T. (1989). Linking service quality, customer satisfaction, and behavioral intention.

Yaong Xiang, Sang Chul Lee, Xiaofeng Li. (2009). The variables of effecting customer loyalty in Chinese online game market.

Yomnak, T. (2009). Perceptions of service quality and customer satisfaction of Thai online shopping services. D.B.A. dissertation, Nova Southeastern University, United States -- Florida. Retrieved September 7, 2009, from Dissertations \& Theses: Full Text. (Publication No. AAT 3255210).

Zee-Sun Yun, \& Linda K. Good. (2007). Developing customer loyalty from e-tail store image attributes. Managing Service Quality, 17(1), 4. Retrieved June 2, 2009, from ProQuest Central. (Document ID: 1204214491)

Zeithaml, V.A, Berry, L.L., and Parasuraman, A. (1996). The behavioral consequences of service quality.

Zeithaml, V.A. (2000). service quality, profitability, and the economic worth of the customer: what we know and what we don't know.

Table 1. Regression output

\begin{tabular}{|c|c|c|c|c|}
\hline \multicolumn{3}{|c|}{ Dependent Variable: Trust \& trustworthiness } & & \\
\hline \multicolumn{3}{|l|}{ Method: Least Squares } & & \\
\hline \multicolumn{3}{|c|}{ Date: 12/24/09 Time: 17:56 } & & \\
\hline \multicolumn{2}{|l|}{ Sample: 159} & & & \\
\hline \multicolumn{3}{|l|}{ Included observations: 59} & & \\
\hline Variable & Coefficient & Std. Error & t-Statistic & Prob. \\
\hline $\mathrm{C}$ & 0.068122 & 0.108760 & 0.626348 & 0.5336 \\
\hline Privacy information & 0.947084 & 0.095990 & 9.866445 & 0.0000 \\
\hline Security & 0.028144 & 0.095193 & 0.295652 & 0.7686 \\
\hline R-squared & 0.974120 & \multicolumn{2}{|c|}{ Mean dependent var } & 2.474576 \\
\hline Adjusted R-squared & 0.973196 & \multicolumn{2}{|c|}{ S.D. dependent var } & 1.119666 \\
\hline S.E. of regression & 0.183312 & \multicolumn{2}{|c|}{ Akaike info criterion } & -0.505746 \\
\hline Sum squared resid & 1.881783 & \multicolumn{2}{|c|}{ Schwarz criterion } & -0.400108 \\
\hline Log likelihood & 17.91950 & \multicolumn{2}{|l|}{ F-statistic } & 1053.917 \\
\hline Durbin-Watson stat & 2.018891 & \multicolumn{2}{|c|}{ Prob(F-statistic) } & 0.000000 \\
\hline
\end{tabular}


Table 2. Regression output

\begin{tabular}{|c|c|c|c|c|}
\hline \multicolumn{3}{|c|}{ Dependent Variable: Loyalty in online marketing } & & \\
\hline \multicolumn{3}{|l|}{ Method: Least Squares } & & \\
\hline \multicolumn{3}{|c|}{ Date: $12 / 24 / 09$ Time: 18:08 } & & \\
\hline \multicolumn{2}{|l|}{ Sample: 159} & & & \\
\hline \multicolumn{3}{|l|}{ Included observations: 59} & & \\
\hline Variable & Coefficient & Std. Error & t-Statistic & Prob. \\
\hline $\mathrm{C}$ & -0.452976 & 0.187403 & -2.417125 & 0.0189 \\
\hline Trust \& trustworthiness & 0.480871 & 0.148881 & 3.229912 & 0.0021 \\
\hline R-squared & 0.964395 & \multicolumn{2}{|c|}{ Mean dependent var } & 2.491525 \\
\hline Adjusted R-squared & 0.963124 & \multicolumn{2}{|c|}{ S.D. dependent var } & 1.072748 \\
\hline S.E. of regression & 0.206002 & \multicolumn{2}{|c|}{ Akaike info criterion } & -0.272353 \\
\hline Sum squared resid & 2.376461 & \multicolumn{2}{|c|}{ Schwarz criterion } & -0.166715 \\
\hline Log likelihood & 11.03441 & \multicolumn{2}{|l|}{ F-statistic } & 758.4136 \\
\hline Durbin-Watson stat & 2.255426 & \multicolumn{2}{|c|}{ Prob(F-statistic) } & 0.000000 \\
\hline & & & & \\
\hline
\end{tabular}

\section{Appendix}

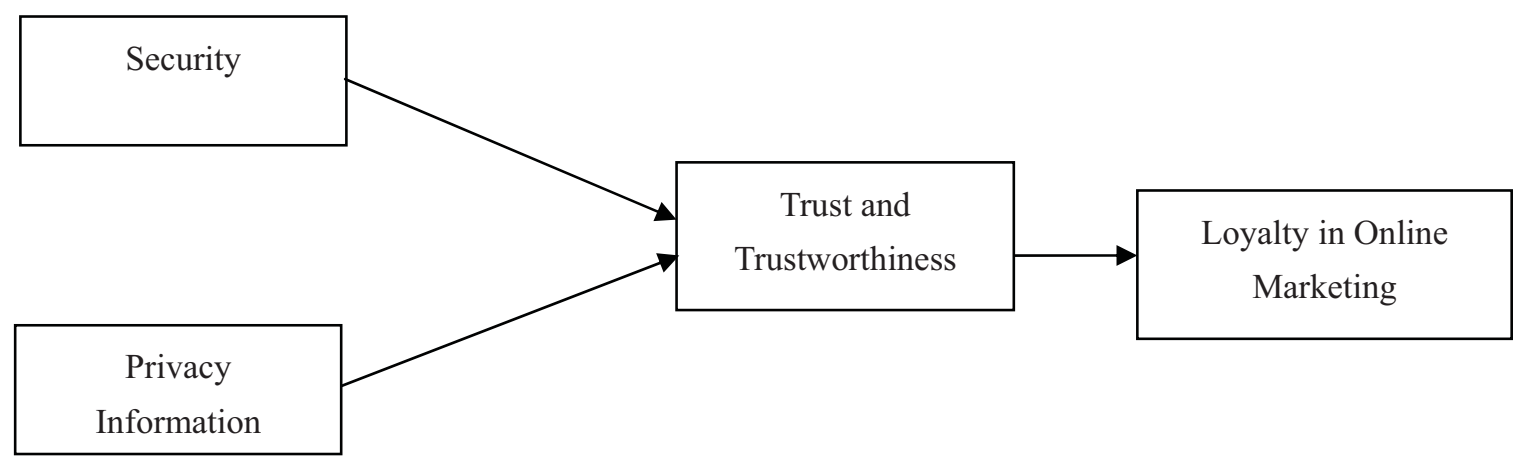

Figure 1. Research Framework 